\title{
Man Slaving to Divine: A Socio-religious Custom Gleaned from the Nineteenth Century Palm Leaves
}

Ignatius Payyappilly*

Abstract

This paper is an attempt to explore and analyse the practice of the institution of slavery observed by the Syrian Christian communities in Kerala. There are eighteenth and nineteenth century palm leaf (manuscript) records in the Syrian Christian churches in Kerala establishing the same which needs to be understood in its secular and spiritual senses since these records are evidence of both the secular practice of slavery as a social custom and a religious practice of adima (slave) offering as a spiritual activity. So also, this paper is an attempt to explore and analyse the origin of adimappanam or adimakasu found in the Church records.

Keywords: Syrian Christians; Slavery; Palm leave records; Adima; Adimappanam; Slave offering

\section{Introduction}

The institution of slavery was a part of the social life of Kerala society until the second half of the nineteenth century. The Syrian Christians who are a decisive part of Kerala society absorbed many social customs in their secular and religious life. There are palm leaf (manuscript) records in the Syrian churches establishing the presence of slavery among the Syrian Christians. The Syrian

* Chief Archivist, Archdiocesan Archives, Archdiocese of Ernakulam-Angamaly, Kerala; ignatiuspayyappilly@yahoo.com 
Christian communities, especially Orthodox, Jacobitei and Catholic communities tolerated and practiced it as part of their life. Besides the palm leaf "slave records" which speak of the slaves under the Syrian Christians, there are many palm leave "church accounts" (day books, monthly and yearly summaries of varavu and chilavu (income and expense) which speak of the adimappanam (slave money) given to the churches as offerings. Therefore, it would be interesting to know about the institution slavery as it existed among the Syrian Christians and the origin of adimappanam or adimakasu found in the Church records. So also, the palm leaf records speak of the practice of giving oneself or a child as a slave to a saint i.e. to the church). Based on these kinds of church records, this article is an attempt to study the social custom of slavery that existed among the Syrian Christians in the context of Kerala from the nineteenth century palm leaves of St Thomas Jacobite Church, Parur; St Mary's Forane Church, Muttam and St Mary's Church, Kudavechoor. Likewise, it is again an attempt to analyse how slavery, as a social practice or custom, was preserved and received religious colouring in the society especially among Syrian Christians in spite of the teachings of the Synod of Diamper and Missionaries.

\section{Historical Background}

Slavery ${ }^{i}$ was considered to be a universal phenomenon that existed in the world including India from time immemorial.ii Excavations at Mohenjo Daro and Harappa, while establishing the existence of high level of civilization, provide evidences for the dasas or dasyu in the social organization. iii Buddhism and Jainism spread across Kerala before the early years of Christian era. Though Buddha was against caste system and varna, he never opposed slavery. Therefore, all types of discriminations based on birth were not discouraged and Buddhism favoured both money lending and slave keeping. So also, Jainism was not far away from the Buddhist approach.iv However, most historians do not accept the existence of slavery in Kerala in the early centuries of Christian era. According to them, the status of the original inhabitants was that of free men and who had their own form of government. The ancient society might have had some form of division of labour which guided the 
day to day life of the people and whatever they produced was for the use of the community and they might have enjoyed social freedom and equality in spite of the social classification based on primary social functions. ${ }^{v}$ Historically it is established that in India, caste system began with the arrival of Aryans which caused the downfall of the primitive social order and the emergence of slavery. ${ }^{\mathrm{vi}}$ And therefore, slavery in Kerala could be interpreted only in the larger background of Indian history and Aryan advent in the South Indian continent. By the fifth century $\mathrm{AD}$, the slow and gradual process of Aryan infiltration radically changed the society with the division of society on the basis of occupation and rituals and made the impassable barrier of untouchability and enslavement. Thus the all pervading influence of the new social order in Kerala due to the Aryan colonization and break-up of primitive society caused the emergence of class-caste society with agrestic slavery as one of its significant characteristic features.vii

The myth of Parasurama and the institution of slavery attributed to Parasurama who is said to have organized the slave caste as a provision for agriculture when he gave the country to the Brahmans narrated in the Keralolpathy, was invoked by the upper castes to justify the institution of slavery and caste system. Actually slavery arose as a result of Aryanization of Kerala and transition of agrarian production from a kin based system of labour to a non kin system of labour headed by the Brahmin household. viii These slaves were originally agrestic and slavery was the basis of agriculture. The services of Pulayas and Parayas were of an outstanding nature and formed the pillar of an agriculture-oriented economy.ix But domestic slavery was almost unknown due to the law of caste system.x Since the origin of slavery was closely associated with the inception of caste system in India, there was a hierarchical social order and the whole structure was given a religious colouring. The terms jati (caste) and varna (colour) are used as synonyms. ${ }^{x i}$ These slave caste people (avarna) had to keep particular distance from the savarna people. The caste system placed the slaves in the lowest strata in traditional society and they were employed only for the praedial work. The custom of untouchability and inapproachability polluted the social life. The system of pollution by proximity and contact was observed in Kerala from very early times and it was in its heights during the medieval period. The pollution by 
approachability was not observed by the Christians.xii But, for the Syrian Christians, their touch was considered polluting and pollution was removed by bath against which the Synod of Diamper made decrees. xiii

\section{The term adima (slave)}

The Malayalam word adiyar for slaves was derived from Tamil word adiyor.xiv Quoting the words of Baber, former collector of Malabar, K P Padmanabha Menon says that the general term for the description of slave is adima (atima) or serf (slave), aboriginal or indigenous being held previously under the same tenures and terms as the land itself.xv According to William Logan the term "adima" comes from the Dravidian term adi meaning slavery, feudal dependencies, who were not formerly allowed to possess land in janmam right and when a janmi made over land to a person in the condition of an adiyan, it was called an adima deed or grant. The right of proprietorship continued with the janmi, and the tenant paid him a small amount (two fanams) annually by way of acknowledgement of proprietorship.xvi Therefore, the terms of adima and kudima mean a slave who is subject to the landlord and who paid a nominal fee to the land lord. The non-payment of the annual fee will form no ground for ousting the grantee, but will be recoverable by action.xvii There were a lot of such people (adima) in the Vembanadu Lake area, which was predominantly agrestic in the eighteenth and nineteenth centuries and agriculture was based on the slave work of the lower caste people such as Pulayas, Parayas, and Ezhavas who never owned the land until the end of nineteenth century.

The landed aristocracy, who controlled the means of production, considered that it is essential to have men to cultivate their lands and tried to keep people with them together with their lands and the social conditions of the time made them slaves. In general, ezhavas, pulayas, pariahs, kuravas, vetars etc. were counted slave castes and considered as outcastes. xviii The landed proprietorship of the time gave rise to a three -tier system of agricultural economy: jenmi- with title of absolute ownership; kudiyan- who took the land on lease and sometimes there were more than one (there were intermediaries too); and the adima (slave) - real cultivator or tiller ${ }^{x i x}$ 
who were entitled to receive only a very small portion of their produce for their livelihood and had no any other right on land or produce.xx Many Syrian Christians who were land owners kept these low caste people with their land like other Janmies.

\section{Early records of slavery}

One of the earliest inscriptions related to "adimakasu" (slave levy) belongs to the ninth century (AD 849). This inscription is said to be the earliest document throwing light on the existence of slavery in Kerala. According to this inscription the Venadu Raja, Ayyan Adikal Tiruvadigal granted certain privileges to the Tharisa Church and community at Quilon (Kollam) and one of these privileges was that the levy of adimakasu (slave money) need not be exacted from this community (Christians). ${ }^{x \times i}$ From this document it is clear that a levy called adimakasu (slave money) was exacted from those who kept slaves in those times and continued in later times too. Again it is an evidence of the existence of the institution of slavery prior to the ninth century and Christians were given the permission to keep the slaves together with many other privileges granted by the local ruler. Abbe J Dubis, while describing the manners and customs of the Hindus that existed in India for hundreds of years, says that the condition of the Pariah, the born slaves in Malabar Coast, resembles to a certain extent that of the serfs of France and other European countries and the ancient institutions such as property rights and slavery are apparently inseparable one from the other. These Pariahs are serfs for life from father to son and were part and parcel of the land. The land owner could sell them with the soil and dispose of them when and how he pleased.xii When a child was born to a slave woman, that child was counted as a slave. The Hindu society justified the institution of slavery in the light of Vedas and Sutras.xxiii

\section{Slave trade in Kerala}

Slave trade became a common practice and spread in Kerala with the arrival of western colonizers. xxiv There are many documents which speak about the sale of slaves and which present the picture of this institution in Kerala. In the slave market slaves were 
bargained and sold. There were special markets to sell and buy the slaves in Kerala. One such market that was famous was in Vadayar near Vaikom.xxv The master (proprietor) could sell his serfs (slaves) and also let them out on simple rent or mortgaged under certain deeds. So also, the master had the right of passing his slaves to another.

There were slaves attached to the temple properties and such slaves were considered to be the properties of Devaswam. People, especially devotees, surrendered their properties such as paddy fields and lands to the temple together with the slaves attached to those properties. In such cases, these salves were considered to be that of Devaswam and could be enjoyed by the Devaswam in the same manner as enjoyed by the previous master or owner. A "tittu" (document) of 856 Malayalam Era (AD 1681) is an example for the same.xxvi Likewise, Rajas (local kings) also handed over the proprietorship over the slaves to the individuals or to the temple together with the properties given to them. For example, a thitturam (royal writ) from the Raja of Cochin to Ayyanatt Krishnan written in $957 \mathrm{ME}(1782 \mathrm{AD})$ allows Krishnan to enjoy the ownership of slaves attached to the land given by the Raja.xxvii

Even the early Europeans took part in the slave trade. The Portuguese and Dutch used to buy slaves in large numbers. ${ }^{x x v i i}$ Quoting Dr Francis Day, historians observe: "report says that the church (in Cochin) was occupied as a slave godown on special emergencies and that, in the weekdays, when the sacred edifice was not required for religious purposes, it was employed to keep these unfortunate creatures in who had usually been carried off by the Moplas and sold to the Dutch, who shipped them to Cylone, Batavia, the Cape and other places". xxix "In 1812 Col. Munroe, The British Resident in Travancore and Cochin discovered a number of half-starved and naked natives in iron as slaves at the Dutch settlement at Changanassery. It is stated that the Portuguese used the church at Cochin to lodge the slaves without prejudice to the demand of divine service". ${ }^{x x}$ Even under the English East India Company administration, slaves continued to be a marketable commodity and were sold for the realization of land revenue and decree-debts.xxi In 1819, when the Travancore government gave the Munroe Island to the Church Mission Society there were about 100 
slaves who have been handed over to the Society together with the land. xxxii

\section{Abolition of slavery}

The English a Government took all the measures to abolish slavery and slave trade in India including Kerala. In 1792 a proclamation was issued by the Commissioners against dealing in slaves and the slave dealer was treated as a thief and people who conveyed slaves were severely flogged and fined.xxiii But, the anti-slavery move became strong at the time of Col. Munroe. ${ }^{x x x i v}$ Anti-slavery movements have got two phases: in the beginning it was against the slave trade and Christian missionaries (CMS) were working for that and the second phase was abolition of slavery itself. In the beginning it was not easy to think about the abolition of slavery since it was considered as a social institution and agriculture production was totally depended on these slaves. Moreover it was a source of income for the government too. ${ }^{x \times x v}$ In 1819 orders were issued stopping the sale of slaves for arrears of revenue and in 1843 the British government of India passed laws abolishing slavery altogether. But, the slaves were free to remain with their masters or to leave them. So also, any person claiming a slave as janmam, anam or Panayam, the right of such claim was not investigated by any public body. However, the slavery and slave trade still continued till the proclamation of 1853 in Travancore.xxxvi And by 1855 all kinds of slavery were abolished by law in Travancore and the Raja of Cochin followed this example a few years later. xxxvii According to the census of 1836 there were 1,64,864 slaves in Travancore State out of the total population of $1,280,668$ while the census of 1857 shows that the slave population in Malabar was 1,87,812.xxxviii

"Though they were freed, they had neither land nor necessary economic background to support them. The landed properties were still the monopoly of the high class and it continued in the traditional pattern".xxxix Therefore, these landless people had to wait many more years to have their own properties. The Missionary records provide pictures of slave Christians (new converts from slave castes) and their terrible economic position. They had to work and live like agrestic slaves and it continued even after the formal abolition of slavery in 1855. Likewise, 
missionary narratives pictured the cruelties of upper caste Nayers as well as Syrian Christian landlords and various strategies played by these oppressed class to escape these cruelties and exploitation even at the end of nineteenth century. ${ }^{x l}$ As Marc Bloch said, social needs in each society prompted it to develop a great number of customs and "custom that finally decided the fate of the legal heritage of the preceding age. Custom had become the sole living source of law, and princes, even in their legislation, scarcely claimed to do more than interpret it. The progress of this customary law was accompanied by a profound reorganization of the legal structure". Each human group, great or small, tends to develop its own legal tradition and made customary laws for the society. ${ }^{x l i}$

\section{Syrian Christians and slavery}

In Kerala, the institution of slavery among Syrian Christians has to be understood in its secular and spiritual senses because the church records give evidence for both the secular practice of slavery as a social custom and a religious practice of adima (slave) offering.

\section{Slavery: A social custom}

Syrian Christians, who claimed the superior social status in the society, and were treated on par with the upper castes, had the tendency to follow the customs of the upper class people in the society. xlii Therefore, they were not much different from the Hindu savarna people in their approach towards the slaves and they possessed slaves and considered this institution of slavery as part of their social life. The Synod of Diamper insisted that the Nazranikal (Syrian Christians) stop many local social customs and practices related to the Hindus. xliii But, the Synod Decrees did not speak anything against the adima (slavery) that existed among them. However, one of the Decrees speaks about the baptism of the slaves and their children and the ban of sale of those slaves who wish to be baptized to non-Christians. Likewise, the Synod decreed that the Nazranikal should baptize the Velladikal (salves) who are under them and not to sell or buy Christian children as slaves.xliv Moreover, Portuguese people, who took the initiative for the Synod, also practiced slavery and slave trade and the Portuguese 
influence was high among the Christians. Therefore, slavery has continued among the Syrian Christians until the second half of nineteenth century.

There are eighteenth and nineteenth century records which speak of slavery among the Syrians. The following letter of a father is an example: "Father's letter: To let my son-in-law know: Kurumba, a Pulaya woman and Kunjan, a Pulayan whom I bought 'theeru' (slave deed) from Vellattummel Chinmar by paying the price, and as I sold Kurumba, the Pulaya woman, to Palliyakkal Muriyil Chanku Nayar and her daughter Ayya (whom Kurumba gave birth) to Eeraly Ittichan Vareethu in Parur market (Angady) in Dhanu month in the year 1017, I give Kunjan, a Pulayan to you as part of dowry (stridhanam) together with 300 Puthan and I give theeru (written document) and agree that hereafter myself or my descendants will not have any right over him (Kunjan) $11^{\text {th }}$ of Vrischika month in the year 1018 written by Thalayaveettil Govindan Padmanabhan witnesses Eraly Ittichan Vareethu Kattappurath Vareethu letter known (witness) + signature". xlv

Syrian Christians participated in the slave business too. Land owners bought the slaves either with land or without land. The following deed is an example. "Transfer deed on 17th Kumbham 1020 Kollam year (AD 1845) whereby Govindapuram Desath Cheerattamannu Eravi Parameswaran transfers his ownership of Amrithi, the male Pulaya and Mani, the female Pulaya born as the children of Nalathramani after receiving by cash 601 Chakrams (Rs. 21) to Enathikkal Thomman Varkey".xlvi Another example: "This is the Artha Pattu seetu (slave deed) given by Cheerattamannu Eravi Parameswaran of Govindapuram to Enathikkal Thomman Varkey on Kumbham (month) 17th in the year 1030 M.E. (A D 1855): among the Pulayas, Amrithy, a Pulayan, one of the children gave birth by Nalathra Mani, together with Mani, a Pulaya woman, are given to Olassa karayil Enathikkal Thomman Varkey by Eravi Parameswaran, Adiyor of Manali Illam (Tharavad) written and given this artha pattu seetu (of the right) by receiving the price decided-Chakram 601- from Thomman Varkey by Eravi Parameswaran. And witnesses for this: Olassa karayil Edapparambathu Raman Kesavan; Pulickaparambil Itty Itty"xlvii 
There is another document of AD 1859 from St Thomas Jacobite Church Parur which gives a list of deeds placed before the kaikkaran (trustee) of the church by a parishioner together with a complaint to be solved by the trustee. The list of deeds includes one melola (palm leave) regarding Pulaya mortgage written and given with all rights on a Pulayan (slave); one vellola adharam (palm leaf deed) related to the sale of a slave in the market; one artha pattu seetu (receipt) etc. together with the details of the seller, buyer, slave, and witnesses etc.xlviii

Sometimes slaves were mortgaged by the owners. According to a document preserved in the State Archives, Thiruvanthapuram, belonging to the Mar Thomma Jacobite Syrian Cathedral church, Mulanthuruthy, Ernakulam, a Syrian Christian called Varkey Chacko pledged a slave woman called Kochu to the church as a security for 10 parahs of paddy received from the church. He agreed to leave her at the service of the church if he failed to return the paddy on time.xlix According to another document in the same church one Chacko Ittuppu pledged one bullock for five parahs of paddy which was equal to the value of a slave." "They were generally but not always sold with the land. A pair of slaves may be worth four pair of buffaloes. They were also let out and pledged. They got an allowance of rice and a cloth." Says William Thackeray in his report on the Revenue Affairs of Malabar and Canara dated September 7, 1807.li

These documents are very important because these kinds of sale and transactions of slaves took place even after three decades of the historic proclamation of Rani Lakshmi Bai of Travancore in 1812 by which the suppressed classes secured many privileges. ${ }^{\text {ii }}$ Muhammadans (Muslims) and Roman Catholics purchased slaves in order to proselytize them to their own religion and these slaves were sometimes compelled even to separate themselves from the rest of the family. liii Following the instruction of the Synod of Diamper, Syrians very often baptized their slaves though these lower class people did not enjoy any economic or political freedom. Change of religious faith did not bring forth any economic or social progress in their life. 


\section{Slave offering: A religious practice}

It is true that once slavery was abolished by law (1855 AD) and the practice of the same was punishable, Syrian Christians also stopped it. Together with the legal abolition, the Christian Missionary activities especially that of CMS Missionaries in the middle of 19th century and large number of conversion of Pulayas and Ezhavas to Christian faith encouraged the native Syrian Christians to abandon this practice. However, age old mentalities were not changed and it took many years to change their attitude towards the lower class people. Early Church records often remain as evidences of these mentalities. There are many palm leaf records (day books or monthly summary reports of church income) of nineteenth century which refer to the adimappanam (slave money) paid to the church as a religious offering.

For example: 1) Income record of $1003 \mathrm{ME}$ (1828 AD): "Income: account of the income of Muttam church: Chakram varavu (income) after deducting the upakari (particular portion) from stridhanam (dowry) Chakram 300 of the daughter of Chennare chackyan=13 3/4 ; income from offering box= Chakram 5; $8^{\text {th }}$ :Chakram from sthapassu kurbana (holy Mass) said by Ittare achan (priest) $=6$; Mamala achan (priest) Raza (holy Mass) 1= Chakram 12; kuzhikkanam (tomb fee) of Chirackal Ouseph= Chakram 301; rent for big silver cross $=$ Chakram $85 \frac{1}{2} ; 14^{\text {th }}$ : Chakram from Raza kurbana (High solemn Mass) said by Fr Vicar =12; adima vacha Varavu (slave money as part of giving the child as a slave) $=$ Chakram $7 "$. liv

2) "Varavu nalvazhi (income day book) 20th Edavam (month) $1044 \mathrm{M}$ E (1869 AD): Meenattukare Varkey's son adima vacha varavu (offering as slave money given to the church) $=$ Chakram $10^{\prime \prime} \mathrm{lv}$

3) "Varavu (income) 11 th Chingam (month) 1046 M E (1871 AD): Pulickal Vareethu's child adima vacha varavu (offering as slave money given to the church) $=$ Chakram $10^{\prime \prime}$ lvi

According to the original meaning of the term adimappanam, it "was the yearly payment of one or two fanams, which every Adiyan was obliged to pay to his Tampuran or patron, whether he was Raja, Naduvali, Desavali or other great man". "vii It can be interpreted as the tax paid to the landlord or to the government in relation to slaves. But, these church account records show that the adimappanam is 
given to the church as an offering and not paid as part of the slave tax or rent. Once they are offered as slave, they have to free themselves (regain the slave) by paying a small amount to the church. This money is called adimakasu or adimappanam (slave money) in the church records which is different from the slave money in the secular sense. Sometimes people used to continue this practice (offering) for a particular age or period as a part of their veneration and piety. In the beginning of nineteenth century it was only one Chakram and slowly it was increased up to 10 chakram by the middle of the century.

From the beginning of the sixteenth century, with the arrival of Portuguese Missionaries, there started the flow of conversion from the lower caste to Christianity. These newly converted Christians, who were once salves, might have shown the tendency of offering themselves as slaves to their new Masters, that is, Saints. This practice of offering themselves or their children as slaves to the churches (following the practice of offering the children to the Master by slave women) as a spiritual offering to saints, especially to Blessed Virgin Mary and St Thomas, St George etc for their special intercession and protection as in the case of slaves where the master gave protection to his slaves, is an expression of their religious faith. The very prayer said by the priest at the time of blessing itself is an expression of slavery. According to this spiritual practice, the one who is offered as a slave has to spend some time in prayer and sit in the church and has to do some menial jobs like sweeping etc. in the church. Before leaving the church they have to go to the priest for the priestly blessing and the blessing prayer (Syrian Catholic prayer) begins with calling the name of the person: "(Name), I declare you as slave of (name of the saint to whom the person is offered) let him/her be your model and master" lviii Therefore, this offering of child as a slave to the church is only a religious practice though it has been developed from a social practice and has the characteristics of a social custom.

Non-Christians (Hindus) justified the caste system and slavery in the light of Scriptures and gave religious colouring. lix This might has been a temptation to Christians to spiritualize this social custom in the light of the Bible. ${ }^{1 x}$ But the spiritualization was entirely in a different manner, that is, instead of justifying the social 
custom, they adopted it into a religious practice, that is, a social custom has been translated into a spiritual practice and made religious. As Marc Block opines "religious life was also nourished on a multitude of beliefs and practices which, whether the legacy of age-old magic or the more recent products of a civilization still extremely fertile in myths, exerted a constant influence upon official doctrine" ${ }^{\prime \prime}$.xi

"It is customary to draw a distinction between Christian sensitivity to slavery, and the ingrained conservatism of other faiths, but all world religions have wrestled with the problem of slavery. Moreover, all have hesitated between sanctioning and condemning the 'embarrassing institution.' Acceptance of slavery lasted for centuries, and yet went hand in hand with doubts, criticisms, and occasional outright condemnations". ${ }^{\prime x i i}$ Though it is not traceable according to the present available primary sources, that when this practice was started and who initiated it, it can be said as that slave nercha (offering) is a spiritualization of a social custom which continues even today.

\section{Conclusion}

As stated above, Syrian Christians always had the tendency to follow the customs of the upper caste people in the society. This tendency began to be changed from late nineteenth century mainly because of the political and social changes in the society. However, their perception of caste structure and hierarchy and notion of purification etc. still remained even in the second half of twentieth century. The legal abolition of slavery in the middle of nineteenth century did not change the mentality of the people and it took many more years to extend equal status to the lower class people in the society. It was actually colonial modernity, especially education which helped the Indian society, especially Kerala society, to make such a change in the society. It is true that every religion has its own peculiar attitude towards slavery. Syrian Christians gave a religious colouring to this social practice (slavery) but in a different way, that is, a social custom was translated into a spiritual practice, a typical example of their identification with the Indian culture and religiosity. This might have been the cause of the origin of slave nercha (offering) in the Christian churches especially in the Syrian 
Churches which still remains as a religious practice and is a good source of income in the ancient parishes in Kerala. Though it is not possible to draw the beginning of this spiritual practice from the available records, it is true that this practice is being continued even today but is different from the earlier times. The nineteenth century records show the name and surname of the person who does this offering and the amount paid to the church (as individual cases) while at present the church records never gives any hint to the identity of the person and the total amount received as adimakasu is written daily or weekly in the account because by the first half of the twentieth century the system of record writing itself has been changed.

\section{References}

\section{Manuscripts}

Palm leaf Manuscript. (1828). St Mary's Forane Church, Muttam, Cherthala, Palm leave bundle I /1/ leaf 36

Palm leaf Manuscript. (1843). St Thomas's Jacobite Church, Parur, Palm Leave Bundle 26/ leaf 24

Palm leaf Manuscript. (1859). St Thomas's Jacobite Church, Parur, Palm Leave Bundle 7/ leaf 14

Palm leaf Manuscript. (1869). St Mary's Forane Church, Muttam, Cherthala, Palm leave bundle1/1/leaf / 21

Palm leaf Manuscript. (1871). St Mary's Forane Church, Muttam, Cherthala, Palm leave bundle1/1/leaf51

Udayamperoor Synod Canons. (Manuscript of 1768, Serial No 1299). Mannanam, St Joseph's Monastery.

\section{Books}

Bloch, M. (2004). Growth of ties of dependence in L. A. Manyon (Ed.), Feudal society (2 ed., Vol. 1): ebooksfreedownload.org/ 2011/08/feudal-society-vol-1-2.html

Dalit, B. (N K Jose). (2011). Divan munroe (2nd ed.). Vaikom: Hobby Publishers

Dubois, J. A., (1906). Hindu manners, customs and ceremonies. (3 Ed.). Oxford: Clarendron.

Forrestes, D. B. (1980). Caste and Christianity: Attitudes and Policies on Caste of Anglo Saxon Protestant Missions in India. London: Curzon Press. 
Fuller, C. J. (1992). Kerala christians and the caste system. Dipankar Gupta (Ed.), Social stratification (pp. 195-212). Delhi: Oxford University Press.

Gita. (1901), (2 ed.). Tran: A Mahadeva Sastri, Mysore, Government Oriental Library.

Gundert, H. (1844). Translation and Analysis of Ancient Documents Engraved on Copper in Possession of Syrian Christians and Jews of Malabar. In The Madras Journal of Literature and Science, XIII (Part 1), pp. 115-146. Retrieved from http://books.google.co.in/books/ reader?id $=$ bspKAAAAcAAJ\&printsec $=$ frontcover\&output $=$ reader $\&$ source $=g b s \_a t b \_h o v e r \& p g=G B S . P R 2$

Gurukkal, R., \& Varrier, R. (1999). Cultural history of Kerala. (Vol. I). Thiruvananthapuram: Department of Cultural Publications Government of Kerala.

Hunt, W. S. (1997). Slavery in Kerala. In State Editor. Kerala Society Papers, (Vol. I, pp. 275-285). Trivandrum: Kerala Gazetteers.

Iyer, L. A. K. (1939). The Travancore tribes and castes (Vol. 2). Trivandrum: The Superintend of Govt. Press.

Koshy, N. (1968). Caste in Kerala churches. Bangalore : CISRS.

Kusuman, K. K. (1973). Slavery in Travancore. Trivandrum: Kerala Historical Society.

Logan, W. (2010). Malabar Manual (Vol. 1 \& 2, 5th reprint). New Delhi: Asian Educational Services.

Mateer, S. (2006). Native life in Travancore (2nd reprint). New Delhi: Asian Educational Services.

Menon, K. P. \& Padmanabha. (1929). History of Kerala (Vol. 2). Ernakulam: Cochin Govt. Press.

Menon, P. S. (1983). A History of Travancore. Trivandrum: Government of Kerala.

Nair, A. \& K. K. Ramachandran. (1974). Adimatham. In P. S. Velayudhan (Ed.). Kerala Charithram (Vol. 2, Pp. 47-82). Ernakulam: Kerala History Association.

Nair, A. \& K. K. Ramachandran. (1986). Slavery in Kerala, Delhi: Mittal Publications.

Philip, G. (2005). A historical anatomy of the evolution of social revolution in Travancore (Unpublished PhD Thesis). Kottayam: Mahatma Gandhi University.

Pillai, T. K. \& Velu. (1996). The Travancore State Manual (Vol. 3). Thiruvanathapuram: Govt. of Kerala, Kerala Gazetteers Dept. 
Sharma, R. S. (2007). Material culture and social formations in ancient India (2nd ed.). Delhi: Macmillan India Limited.

Smith , G. W., \& Clarence (2006). Religions and the abolition of slaverya comparative approach. Retrieved from http:// www2.lse.ac.uk/economicHistory/Research/GEHN/ GEHNPDF/Conf10_ClarenceSmith.pdf

Viswanathan, S. (1995). The Christianity of Kerala, history, belief, and rituals among the Yakoba. Madras: Oxford University Press.

Worth, J. H. (2005) Questions by a Missionary and Answers by a Travancore Slave Taught in a School of the Church Mission Society, C12/07/24 CMSAUB (Manuscript), quoted by P. Sanal Mohan. (2005). Imagining Equality: Modernity and Social Transformation of Lower Castes in Colonial Kerala (Unpublished PhD Thesis). Kottayam: Mahatma Gandhi University.

\section{Endnotes}

i Slave means the one who is the property of and entirely subject to another person whether by capture, purchase or birth; a servant completely divested of freedom and personal rights (Oxford English Dictionary). Slaves in the context of Kerala are those who "are literally attached to the soil and therefore, transferred with it. When a piece of land is transferred the slaves attached to it ceased to belong to the former owner and becomes the property of the purchaser". Slavery is that condition of servitude. W S Hunt, "Slavery in Kerala", in State Editor, Kerala Society Papers, Vol. I \& II, Kerala Gazetteers, Series 5, Trivandrum, 1997, pp. 275.

iii “Remains of workmen's dwellings have been discovered at Mohenjo Daro and Harappa-parallel rows of two-roomed tiny cottages at Mohenjo Daro with a superficial area of $28 \times 12$ feet each.......... bear striking resemblance of ... workmen's quarters of the modern factory ... built for the dasyus who were slaves". Adoor K K Ramachandran Nair, Slavery in Kerala, Mittal Publications, Delhi, 1986, pp1.

iiv R S Sharma, Material culture and social formations in ancient India, II Edition, Macmillan India Limited, Delhi, 2007, pp.129,165; See also George Philip, A historical anatomy of the evolution of social revolution in Travancore, Unpublished PhD Thesis, Mahatma Gandhi University, Kottayam, 2005, pp.48. 
$\mathrm{v}$ According to $\mathrm{K} \mathrm{K}$ Kusuman, during the second Chera Empire, the pulayas, one of the slave communities of the later period, were an influential and dignified community. K K Kusuman, Slavery in Travancore, Trivandrum, 1973, pp. 25. According to L A Krishna Iyer "a pulaya princess Kotha by name, is said to have ruled over Kokkothamangalam Vellanad pakuthi of Nedumangad taluk". L A Krishna Iyer, The Travancore tribes and castes, Vol. II, Trivandrum, 1939, pp. 120.

viAdoor K K Ramachandran Nair, pp.3.

vii Ibid., pp. 7-9. "Slaves in existence have been slaves from their birth. They were the descendents of slaves whose origin must be traced in the traditional legends of Malabar". Para 9 of the letter of the collector, Calicut, dated July 20, 1818 to the Board of Revenue, Fort St George. Ibid., foot note 4 .

vii Rajan Gurukkal and R Varrier, eds., Cultural history of Kerala, Vol. I, Department of Cultural Publications Government of Kerala, Thiruvanthapuram, 1999, pp. 252-255.

ix K K Kusuman, p. 31; See also Adoor K K Ramachandran Nair, "Adimatham" in Kerala History Association, Kerala charithram, Vol.II, Ernakulam, 1974, pp.47-49.

$x$ Untouchability and inapproachability kept the lower castes away from the upper caste and their dwelling places and the lower castes were not permitted to enter the savarna temples even. However, upper castes used the labour of the Nairs etc. as domestic helpers and companions. K P Padmanabha Menon, History of Kerala, Vol. II, Ernakulam, 1929, pp.272.

xi K K Kusuman, pp.15.

xii According to certain historians, this pollution was not found in case of Mohomedan, Christian and Jew. Making use of this situation, Christian Missionaries attracted these slaves to the Christian faith and thus thousands of them received the Christian faith. Adoor $\mathrm{K} \mathrm{K}$ Ramachandran Nair, pp.38.

xiii Canons of the Synod of Diamper ask the Syrian Christians to stop the practice of pollution by approach and touch and the bath for purification by the same and advices to accept the newly converted coming from lower caste and assemble in the same place for Holy Mass and other Sacraments, because there is no discrimination before God between the upper castes and lower caste. (Malayalam Paper Manuscript, Udayamperoor Synod Canons, Manuscript of 1768, St Joseph's Monastery, Mannanam, Serial No 1299, Book No 9, 7th Yogavicharam, Session IX, 
Canon 2 ) According to Canon 10, The elders and owners (of Velladikal = slaves) should give proper remuneration for their job and converted slaves should be given the opportunity to attend Holy Mass and receive other sacraments. (Ibid, Canon 10).

xiv W S Hunt, p.279; According to K K Pillai, the word Adiyor does not mean slave and probably as distinguished from slaves and it means independent labourer. Adoor K K Ramachandran Nair, Slavery in Kerala, pp. 10.

xv Padmanabha Menon, p.273.

xiv "In Malabar, there are few castes under the rank of Nayar who did not and who do not still acknowdge a feudal dependence upon some superior lord and who are not adiyans or vassals. Persons of this descriptions were not formerly allowed to possess land in janmam right; and therefore, when a janmi made over land to a person in the condition of an adiyan, it was called an adima deed or grant, although he might not be his own vassal, and although the proprietor might have received the full janmam value for the land. The right of proprietorship continued with the janmi, and the tenant paid him a small sum of money which reverted to the janmi on failure of heirs". "The adima grant of a paramba or garden was also often conferred by a superior lord upon his own adiyan or vassal; but here it was in the feature of an Inam or gift, no consideration having been received for it by the proprietor". "The adima grant of a paramba or garden was also often conferred by a superior lord upon his own adiyan or vassal; but here it was in the feature of an Inam or gift, no consideration having been received for it by the proprietor". William Logan, Malabar manual, Vol. II, Madras, 1887 (Fifth AES Reprint: New Delhi), 2010, p. clxvii.

xvii Ibid., p. clxviii.

xvii Adoor K K Ramachandran Nair, p. 24.

xix Adoor K K Ramachandran Nair, p. 25.

xx W S Hunt, p. 275.

xxi "Hail! In the time of Perumal Sthanu Ravi Gupta, who now rules gloriously for many 100000 years, treading under foot hostile heads in his fifth year, this year under the concurrence of His Excellency the Ayyan Adigal governing the Venadu ... the following grant of a freehold.... To the Tarisa church and community established by Isodata Virai of Curakkeni Collam .... There being 61 citizens, the not to be increased nor to be diminished; no personal tax to be received for the slaves they buy (or the person tax to be received)..." This ninth century Deed is one of the 
deeds belonging to the Syrian Christians of the Cochin and Travancore States. This translation by Dr Gundert, appeared in the Madras "Journal of literature , $E c^{\prime \prime}$ Vol. XIII, Part I., P.130 and is quoted by William Logan, pp. cxviii-cxxii; see also, Adoor, pp. 12.

xxii Abbe J Dubis, Translated by Henry K Beauchamp, Hindu manners, customs and ceremonies, Third Edition, Clarendon Press, Oxford, 1906, pp. 56. Dubis's presentation and analysis of Indian slavery is based on his Eurocentric approach in understanding slavery.

xxiii George Philip, p. 104.

xxiv P Sankunny Menon, Thiruvithankoor charithram, pp.288, quoted by Dalit Bandhu (N K Jose), Divan Munroe, 2nd Edition, Hobby Publishers, Ambikamarket, 2011, pp.72.

xxv Ibid.

xxvi Tittu from Karunnukki Tattan Narayanan to the fifteen of Irinyalakuda and to the Muttatu of Kolamanna. As the anger of Kudalmanikkam was found in our tharavadu, we have this day ... surrendered by a document laid on the blessed door .... The lands and parambas . . . and the property and retainers and slaves and others of the above said temples and in addition to this property . . . may be enjoyed forever and ever as devaswam; all the above written property may be enjoyed by the devaswam in the same manner as we are enjoying them ... executed voluntarily with the gift of water janmam by Karumukka Illath Tattan Narayanan . . on the $14^{\text {th }}$ of Chittari month in the year 856 (AD 1681)." Translated from a copy received from the Dewan of Cochin, quoted by William Logan, pp.cxxxvii-cxxxviii.

xxvii" the Thitturam (royal writ) from the Raja of Cochin to Ayyanatt Krishnan: "you are hereby authorized to hold and enjoy on Anubhokam tenure (perpetual one) the following land properties etc . . . and to exercise the right of proprietorship over the slaves named Chattan, son of Ittippengan and Kurumba . . . Dated Chirackal Kovilakam 957(1782 AD), written in the handwriting of Cheruparampattu". Padmanabha Menon, pp. 275-276.

xxviii "The Europeans took very keen interest in the trade of slaves. Even English East India Company Officers were involved in this inhuman practice. The records of the Company reveal that Murdock Brown used to deal in slaves with the active connivance of the Company's Officers. Of the numerous petitions to the court of Foujdaree Adawlut in December 1818 one refers to the purchase of four Channar slaves by one Mr Shepperd, an European who succeeded to the Stamp manufactory at Baypore" Adoor K 
K Ramachandran Nair, pp. 17; Padmanabha Menon says: "the Portuguese and the Dutch were also great sinners in this respect" pp.275.

xxix Francis Day, Land of perumals, Madras, 1863, pp. 183-184; See also Adoor K K Ramachandran Nair, p. 280.

xxx T. K. Velupillai, The Travancore state manual, Vol. III, p. 55.

xxxi Padmanabha Menon, p.275.

xxxii W S Hunt, p.276.

xxxii Padmanabha Menon, p.281.

xxxiv "The tendency gathered momentum during the Residentship of Col Munroe who had the rare privilege of holding the Dewanship of Travancore as well. The political influence of the English and personal interest of Col Munroe enabled Rani Lakshmi Bai to introduce several social reforms". K K Kusuman, pp. 45.

xxxv It is said that there were 165000 slaves in Travancore in 1847 and one panam was paid as tax for each slave and thus the Travancore sirkar levied 165000 panam as tax besides the money collected as rent from the slaves of the sirkar (owned by the government). Dalit Bandhu, pp. 73-75.

xxxiv Padmanabha Menon, pp. 281-282.

xxxvii W S Hunt, pp.276.

xxxviii Adoor K K Ramachandran Nair, pp. 41-42. The census of Travancore in 1891 shows that field labouring class (praedial slaves) has been distributed as follows: 1) Pulayas - 202616, 2) Parayas-71847,3) Kuravas 60377, 4) Others-13818. Ibid., pp. 44.

xxxix K.K. Kusuman, pp. 56.

xl J Hawks worth, 'Questions by a missionary and answers by a Travancore slave taught in a school of the Church Mission Society', C12/07/24 CMSAUB (Manuscript), quoted by P Sanal Mohan, Imagining equality: Modernity and social transformation of lower castes in colonial Kerala, Unpublished PhD Thesis, Mahatma Gandhi University, Kottayam, 2005, pp.39.

xli Marc Bloch, Feudal society: The growth of ties of dependence, Vol. I, Translated by L A Manyon, $2^{\text {nd }}$ edition, London, 2004, pp. 111-112.

xlii St Thomas Christians always claimed that they belonged to the high ranking Nambuthiri Brahmins though it is not fully accepted by all the historians. But the special privileges granted by the local rulers and the 
position enjoyed by the Syrians show that they enjoyed a privileged position in the society. For reference: Susan Viswanathan, The Christians of Kerala; history, belief, and rituals among the Yakoba, Madras, Oxford University Press, 1995; Ninan Koshy, Caste in Kerala churches, Bangalore, CISRS, 1968; C. J. Fuller, "Kerala Christians and the Caste System", in Dipankar Gupta, ed, Social stratification, Delhi, Oxford University Press, 1992, pp. 195-212; Duncan B. Forrestes, Caste and Christianity: Attitudes and Policies on Caste of Anglo Saxon Protestant Missions in India, London, Curzon Press, 1980.

xliii The historical Diamper Synod (1599 AD), convoked by Portuguese missionary Meneziz, Archbishop of Goa has promulgated many decrees regarding the various practices existed among the Syrian Christians and given a lot of directions and decisions to be executed and practiced by the Syrian Christians in Kerala with the intention of wiping out all traces of local influences and Nestorian faith. Udayamperoor Synod Canons, Manuscript of 1768, St Joseph's Monastery, Mannanam, Serial No 1299, Book No 9, 7th Yogavicharam/Mouthwa (Decree), Canons 1-19.

xliv In the Canons (Decrees) of Synod, the term Velladikal is used for the slaves and the term Kavyar is used for the non-Christians. Udayamperoor Synod Canons, 3rd Yogavicharam (Decree) 10th Canon, p. 41. The Synod forbid the Christians not to sell their children or to buy such children or to keep them as slaves and were allowed to buy them only in case of them falling into the hands of Non-Christians. Michael Geddes, The History of the church of Malabar, London, 1964, Action IX, Canon Decree 13, p. 401; See also Bible, New Testament, 1 Corithians 7: 21-24.

xlv Palm leaf Manuscript, St Thomas's Jacobite Church, Parur, Palm Leaf Bundle 26/ leaf 24. This single document is not only a proof of slavery practiced among Syrian Christians but an evidence of slave market in Parur, the worst face of slavery (destruction of a family by separting the members and selling them to three different masters), practice of giving slaves as part of dowry and the practice of preserving a copy of 'dowry record' in the church as an evidence to avoid future disputes.

xlvi Adoor K K Ramachandran Nair, pp. 23.

xlvii E. V. John, History of Anglican Church in Travancore and Cochin, quoted by W. S. Hunt, p.276.

xlviii "List of deeds placed before Kaikkaran (trustee) Kujnipoulo as complaint [avalathy] (to be solved) in the year 1034 M.E.(A D 1859): melola (palm leave) -1[regarding] Pulaya mortgage deed (panaya adharams) 
written by Payyappilly Itteera Ouseph; adharam (deed) -1 ; written and given with all rights by his (Payyappilly Itteera Ouseph) father-in-law [regarding] on Kunjnan, a Pulayan; vellola adharam (palm leaf deed) -1; written for buying Pulayas from Thaikkoottathil Ittiyathi Krishnan [belonging] to Bhavakkadu muriyil Vadakkekkare pravrithyil; do artha pattu seetu (receipt) - 1 ; adharam (deed)- 1 for [regarding] buying a Pulaya, written and received by Eraly Ittichan Vareethu from ...likkara Pravarthyil Puliyamthuruthukarayil Irumpamparambil Varkey; do artha pattu seetu (receipt)-1 ; theeradharam (deed) - 1 written and given to Ittichan Vareethu Ouseph [who] placed the [above] deeds; pattacheetu (pattam receipt)-1 written and given by [above said] Ouseph for Theracka land in the year 1024(M.E.)". (Palm leaf Manuscript, St Thomas's Jacobite Church, Parur, Palm Leaf Bundle 7/ leaf 14.)

xlixK K Kusuman says "the date of the document is not clear but it seems to belong to the early part of the British supremacy at Cochin and a copy of the document is preserved in the State Archives at Trivandrum". K K Kusuman, pp. 39.

${ }^{1}$ According to Kusuman "there was another noteworthy document in this Syrian church which helps us to have an idea of the relative value of a slave in terms of a bullock. It speaks that one Chacko Uduppu as having pledged his bullock for five parahs of paddy and the rest of the conditions are similar to the first one". K K Kusuman, pp.162.

li Adoor K K Ramachandran Nair, pp. 31.

lii Ibid., pp. 24.

liii Samuel Mateer, Native life in Travancore, 2nd reprint, Asian Educational Services, New Delhi, 2006, p. 297. The slaves were sometimes compelled to separate themselves from the husband, wife, children etc. For example: "Wattacherry Syrian Christian family have four slave women, who had been married, but were compelled to separate from their husbands and to take others chosen for them by their masters". Samuel Mateer, pp. 303. See also foot note 45 .

liv Palm leaf Manuscript, St Mary's Forane Church, Muttam, Cherthala, Palm leave bundle I / 1 , Ola leaf 36 .

lv Ibid., I /J, Ola leaf 21.

lvi Ibid., I /J, Ola leaf 51.

lvii I think that William Logan gives this statement on the basis of the practice that existed in Malabar in the $18^{\text {th }}$ and $19^{\text {th }}$ century. William 
Logan, Malabar manual, Vol. II, Madras, 1887 (Fifth AES Reprint: New Delhi, 2010), pp. ccxxxiv.

lviii Book of Blessings

lix Vedic literature, especially Rig Veda, describes how the Aryans protected themselves keeping the Dasyus under their power. Adoor K K Ramachandran Nair, pp. 6. The proponents of caste system and slavery always turned to Gita and Manu Smriti to draw sanctions divinely ordained rules to support their arguments. According to them the four castes have been created by Iswara according to the distribution of energies and of sanctions. The energies are Sattva, Rajas and Tamas. In Brahman Sattva predominates and in the Sudra Tamas predominates and the action of Sudra is servitude. Gita, Tran: A Mahadeva Sastri, 2nd Edition, Mysore, 1901, p. 110, quoted by K K Kusuman, Slavery in Travancore, Trivandrum, 1973, pp. 16-18.

lx In the Bible there are references regarding slaves and attitude towards them both in the Old Testament and New Testament. But these passages do not speak against slavery. E.g. Exodus 21: 1-11; Deuteronomy 15:12-18; Ephesians 6:5-9; 1 Thimothy 6:1-2.

lxi Marc Bloch, Feudal Society: The growth of ties of dependence, Vol. I, Translated by L.A.Manyon, $2^{\text {nd }}$ edition, London, 2004, pp. 82.

lxiiWilliam G. Clarence-Smith, "Religions and the abolition of slavery - a comparative approach" This article give a wide picture of the attitude of Christians, especially that of Catholics, Orthodox and Protestant, towards slaves and institution of slavery. http:// www2.lse.ac.uk/ economicHistory/Research/GEHN/GEHNPDF/Conf10_ClarenceSmith. pdf 